\title{
Accumulation of cesium and strontium from contaminated soils by some "bioenergy" crop varieties
}

\author{
A.J. Grebenkov, S.F. Timofejev ${ }^{1}$ and H. Vandenhove ${ }^{2}$ \\ Institute of Power Engineering Problems, 99 Akademik Krasin Str., \\ Sosny, 220109 Minsk, Belarus \\ 'Research Institute of Radiology, 16 Feduninskogo Str., 246050 Gomel, Belarus \\ ${ }^{2}$ Belgian Nuclear Research Centre, SCK-CEN, 200 Boeretang, $2400 \mathrm{Mol}$, Belgium
}

\begin{abstract}
One of the options of contaminated site remediation strategy is culturing the crop varieties, which have biomass yield high enough to be further used as a local fuel in contaminated regions. A number of field tests of two "bioenergy" crops, namely Brassica juncea and Salix viminalis was carried out. The study was focused on accumulation ability of the given varietics in extracting ${ }^{90} \mathrm{Sr}$ and ${ }^{137} \mathrm{Cs}$ from contaminated soil. Two types of soil, peaty and sandy, were examined. For Brassica juncea, the accumulation factor of ${ }^{90} \mathrm{Sr}$ was about two orders of magnitude higher than that of ${ }^{137} \mathrm{Cs}$. For Salix viminalis, leaves had twofold higher capability to accurnulate ${ }^{90} \mathrm{Sr}$ and more than threefold higher capability to accumulate ${ }^{137} \mathrm{Cs}$ compared to stems. In our example, the peary soil contained higher content of exchangeable forms of $\mathrm{Ca}$ and $\mathrm{K}$ compared to the sandy soil. This was a reason that radionuclide accumulation factors were higher for willow grown on a sandy soil. It was also revealed that ratio between exchangeable and total forms of both radionuclides was relatively high in sandy soil, and this also caused the higher accumulation factor for willow grown on a sandy soil type compared to a peaty one.
\end{abstract}

\section{INTRODUCTION}

In Belanus, more than 1.8 million hectares of agricultural lands were exposed to radioactive fallout, and almost $20 \%$ of them have been excluded from economic turnover. Today, 15 years after Chemobyl Accident, economical and environmental remediation of contaminated farmlands become a key problem. Any countermeasure envisages either treatment of contaminated soil that mitigates negative effect of radionuclides on food chain, or creation of favorable conditions for safe reuse of contaminated lands with culturing the nonfood market oriented products. As to the later, the replacement of food crop species by some technical crops is exercised now. One of the options that could be successfully applied to agricultural practice is culturing the crop varieties, which have biomass yield high enough to be further used as a local fuel in contaminated regions. Despite the fact that such crops are not a part of human food chain, they nevertheless come within restriction that stipulates their use as a fuel.

In the present study, we carried out a number of field tests of two "bioenergy" crops, namely Brassica juncea and Salix viminalis. In addition to investigation of some parameters important for biomass-to-energy conversion, i.e. growing conditions and yield, the study was focused on accumulation ability of the given varieties in extracting ${ }^{90} \mathrm{Sr}$ and ${ }^{137} \mathrm{Cs}$ from contaminated soil. Along with our data already reported in $[1,2]$, the results of the given study can be used for assessment of radiation risk from application of contaminated biomass in conversion processes that will further allow evaluating feasibility of bioenergy production from the identified crop varieties grown in affected regions.

\section{MATERIALS AND METHODS}

\subsection{Willow}

In May 1997, four plantations of willow were established at Savichy Research Base and Masany Research Station in Gomel Province within 30-km zone of Chemobyl Power Plant. In each plantation, four willow clones were planted with fourfold replication. The clones are Rapp, Orm and Jorr (Salix viminalis), and Bjorn (S. viminalis $\times$ S. schwerinii). The general parameters of the plantations are presented in Table 1 . 
Table 1. Parameters of willow plantations

\begin{tabular}{|c|c|c|c|c|c|c|}
\hline \multirow{2}{*}{$\begin{array}{l}\text { Location } \\
\text { and field \# }\end{array}$} & \multirow{2}{*}{$\begin{array}{l}\text { Landscape and } \\
\text { soil type }\end{array}$} & \multirow{2}{*}{$\begin{array}{c}\text { Planting } \\
\text { date }\end{array}$} & \multirow{2}{*}{ Area } & \multirow{2}{*}{$\begin{array}{c}\text { Density } \\
\text { (cuttings/ha) }\end{array}$} & \multicolumn{2}{|c|}{ Contamination $\left(\mathrm{kBg} / \mathrm{m}^{2}\right)$} \\
\hline & & & & & ${ }^{137} \mathrm{Cs}$ & $90 \mathrm{Sr}$ \\
\hline $\begin{array}{l}\text { Savichy, } \\
\text { Field \#! }\end{array}$ & $\begin{array}{l}\text { Poorly drained dry meadow, } \\
\text { Soddy-podzolic sandy on glacial sand } \\
\text { superseded with loose sand }\end{array}$ & $05 / 05 / 97$ & 0.26 & 18000 & $1427 \pm 94$ & $167 \pm 14$ \\
\hline $\begin{array}{l}\text { Savichy, } \\
\text { Field \#2 }\end{array}$ & $\begin{array}{l}\text { Lowland, } \\
\text { Peaty-marsh on medium-thick well } \\
\text { decomposed sedge-reed-woody peat }\end{array}$ & $04 / 05 / 97$ & 0.30 & 18000 & $12876 \pm 2275$ & $1368 \pm 122$ \\
\hline $\begin{array}{l}\text { Masany, } \\
\text { Field \#3 }\end{array}$ & $\begin{array}{l}\text { Former arable land, } \\
\text { Soddy-podzolic, sandy-loam based on } \\
\text { alluvial gleic slsallow-grainy sand }\end{array}$ & $09 / 05 / 97$ & 0.12 & 18000 & - & - \\
\hline $\begin{array}{l}\text { Masany, } \\
\text { Field \#4 }\end{array}$ & $\begin{array}{l}\text { Wetland, } \\
\text { Peat bog of lowland type }\end{array}$ & $08 / 05 / 97$ & 0.10 & 18000 & $2857+365$ & $2659 \pm 1120$ \\
\hline
\end{tabular}

It has to be noted that growth of the willow plantations established on the both sandy fields was not successful. Willow in Masany sandy soil died almost all within the first growing season. In Savichy sandy soil, the plantation was a bit more successful and has survived with mortality rate of about $40 \%$.

During the first cutting-back, willow biomass and soil matter was sampled to determine radionuclides content and principal nutrient concentration. Before measurements, eight soil samples from each test field were taken with $25-\mathrm{cm}$ cores, homogenized, oven-dried and sieved. Stems and leaves of a willow plant (10 samples per each variety plot) were sampled separately, oven-dried, ground, homogenized, and two samples from the homogenized mixture were taken for further measurements.

\subsection{Rape}

In August 1997, the test field of Brassica juncea was established in exclusion zone nearby Savichy Research Base, Gomel Province. Soil type is a soddy-podzolic, loose loamy sandy soil on glacial associated sand superseded with loose sand. The test field was formed with plots to provide fivefold repetitive scheme. The size of each plot was $5.0 \mathrm{~m} \times 2.5 \mathrm{~m}$. Sowing was carried out manually with density of $7 \mathrm{~kg} / \mathrm{ha}$, the distance between rows being $30 \mathrm{~cm}$. Tendance of the plantation was provided manually, including watering, weeding and clearing.

The main feature of soil was acidity coupled with low content of organic matter and mineral components (Table 2). The doses of lime fertilizer (dolomite powder) were estimated according to value of $\mathrm{pH}$. One third of the dose was introduced while ploughing, and the balance was introduced before sowing. The optimal value of $\mathrm{pH}=6.0$ was achieved by adding of $\mathrm{CaCO}_{3}$. The doses of mineral fertilizers were evaluated according to norms taking into account the yield of mineral components with harvest assuming the later to be normally about $2000 \mathrm{~kg}$ of seeds per hectare.

The sampling of biomass and soil was performed at a rosette phase when the yield of rape from the test field achieved $0.68-0.81 \mathrm{~kg} / \mathrm{m}^{2}$ (green mass).

Table 2. Rape test field main characteristics

\begin{tabular}{|c|c|c|c|c|c|c|c|}
\hline Test plot \# & $\mathrm{p} \overline{\mathrm{H}}$ & \multirow{2}{*}{$\begin{array}{c}\text { Total } \mathrm{C}, \\
\%\end{array}$} & \multicolumn{2}{|c|}{ Exchangeable forms, mg-eq/100g } & \multicolumn{2}{c|}{ Contamination $\left(\mathrm{kBq} / \mathrm{m}^{2}\right)$} \\
\cline { 5 - 8 } & & $\mathrm{K}$ & $\mathrm{Ca}$ & $\mathrm{Mg}$ & $137 \mathrm{Cs}$ & $90 \mathrm{Sr}$ \\
\hline 1 & 4.34 & 0.91 & 0.13 & 1.79 & 0.25 & 426 & 45.5 \\
\hline 3 & 4.10 & 0.85 & 0.17 & 1.59 & 0.30 & 531 & 41.8 \\
\hline 5 & $4 . \overline{32}$ & 0.93 & 0.27 & 1.71 & 0.21 & 430 & 42.9 \\
\hline 7 & 4.54 & 0.87 & 0.22 & 1.80 & 0.39 & 332 & 45.5 \\
\hline 9 & 4.41 & 0.90 & 0.20 & 1.74 & 0.41 & 397 & 54.4 \\
\hline Average & 4.34 & 0.89 & 0.20 & 1.73 & 0.31 & $423 \pm 72$ & $46.0 \pm 4.9$ \\
\hline
\end{tabular}




\subsection{Analysis of Samples}

The permanent and time dependent soil characteristics were defined with atomic-absorption analysis. To provide elemental analysis of the samples the ICP PLASMA spectroscope was used. Exchangeable forms of the measured nutrients and radionuclides were extracted with IN acetous ammonia.

Content of ${ }^{137} \mathrm{Cs}$ in the samples was measured using a Ge(Li) detector system with a NaI(Tl) annulus. Two spectrometers were used, i.e. ADCAM-300 and NOKIA LP-4900.

Content of ${ }^{90} \mathrm{Sr}$ in the soil samples was determined by means of radiochemical method. The probe is formed from the samples ashed with $\mathrm{HCl}$ acid solution of $6 \mathrm{M}$ during 6 hours at $600^{\circ} \mathrm{C}$ followed by washing in ammonia solution at $\mathrm{pH}=8$. Strontium is extracted in a form of carbonates. For plant matter, the probe is formed by ashing with concentrated $\mathrm{HCl}$ acid solution until forming oxalates during 7-20 hours at $500-600^{\circ} \mathrm{C}$ followed by transferring oxalates into their oxides at $700^{\circ} \mathrm{C}$ and cleaning against other radionuclides. The daughter isotope, ${ }^{90} \mathrm{Y}$ is extracted in a form of its oxalate and counted after 14 days. The chemical yield of ${ }^{90} \mathrm{Sr}$ is determined by an atomic adsorption spectrometer, while ${ }^{10} \mathrm{Y}$ is measured by weighing. Measurements of the targets were provided by Beta-spectrometer CANBERRA-2400.

\section{RESULTS AND DISCUSSION}

\subsection{Willow}

Average values of specific activity of two soils at Savichy fields and content of exchangeable forms of ${ }^{137} \mathrm{Cs}$ and ${ }^{90} \mathrm{Sr}$ as well as content of cations are presented in Table 3.

Table 3. Content of cations and radionuclides in soils of Savichy test fieids

\begin{tabular}{|c|l|l|l|l|l|l|l|}
\hline \multirow{2}{*}{ Soil type } & \multicolumn{3}{|c|}{ Cations, mg-eq/100g } & \multicolumn{2}{c|}{$\begin{array}{c}\text { Exchangeable forms, } \\
\mathrm{Bq} / \mathrm{kg}\end{array}$} & \multicolumn{2}{c|}{$\begin{array}{c}\text { Total radionuclide } \\
\text { content, } \mathrm{Bq} / \mathrm{kg}\end{array}$} \\
\cline { 2 - 8 } & \multicolumn{1}{|c|}{$\mathrm{K}$} & \multicolumn{1}{|c|}{$\mathrm{Ca}$} & \multicolumn{1}{|c|}{$\mathrm{Mg}$} & \multicolumn{1}{|c|}{$137 \mathrm{Cs}$} & \multicolumn{1}{c|}{$90 \mathrm{Sr}$} & \multicolumn{1}{|c|}{${ }^{137} \mathrm{Cs}$} & \multicolumn{1}{c|}{$9 \mathrm{Sr}_{\mathrm{Sr}}$} \\
\hline Sandy (field \#1) & $\mathbf{0 . 0 3 8 8}$ & 0.890 & 0.02 & 108.25 & 399.5 & 4030 & 472.5 \\
& $( \pm 0.0075)$ & $( \pm 0.101)$ & & $( \pm 3.40)$ & $( \pm 5.5)$ & $( \pm 242)$ & $( \pm 10.7)$ \\
\hline Peaty (field \#2) & $\mathbf{0 . 1 5 5}$ & 11.13 & 1.18 & 2985 & 10550 & 139350 & 14810 \\
& $( \pm 0.062)$ & $( \pm 0.22)$ & $( \pm 0.16)$ & $( \pm 359)$ & $( \pm 790)$ & $( \pm 26510)$ & $( \pm 1010)$ \\
\hline
\end{tabular}

In our example, peaty soil (field \#2) contained approx. 12 times as much of exchangeable forms of $\mathrm{Ca}$ and 4 times as much of that of $\mathrm{K}$ compared to sandy soil (field \#1). Under this condition, for the peaty soil, equilibrium between the nature analogues $(\mathrm{K}-\mathrm{Cs}, \mathrm{Ca}-\mathrm{Sr}$ ) is shifted towards calcium and potassium. As a result, a ratio of exchangeable forms of radionuclides to their total specific activity is lower for a peaty soil than for a sandy one (for $137 \mathrm{Cs}$, see Figure 1).

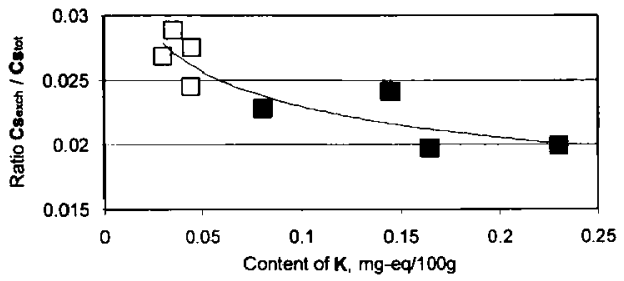

Figure 1: Relation between concentration of ${ }^{134} \mathrm{Cs}$ exchangeable forms and $\mathrm{K}$ content for Savichy fields. Blank boxes refer to sandy soil 
Since exchangeable forms of the given radionuclides are biologically easy assimilable, the noted difference results in the fact that extraction of ${ }^{137} \mathrm{Cs}$ and ${ }^{90} \mathrm{Sr}$ from sandy soil is more intensive (Figure 2). The data obtained also confirm that there is no significant difference of accumulation coefficient between different clones of willow. In the given paper, the accumulation coefficient is defined as a ratio of radionuclide specific activity in willow tissue to that in soil.
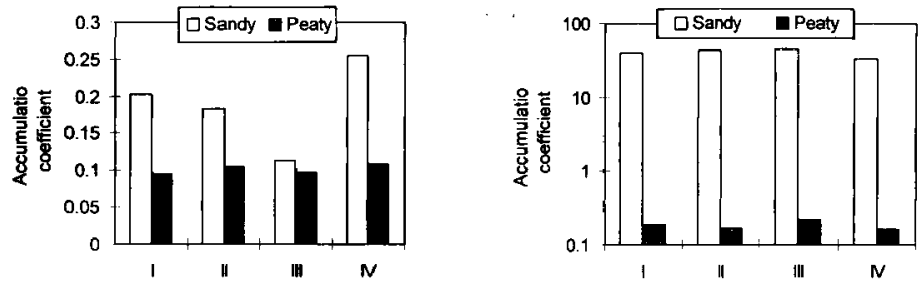

Figure 2: Accumulation coefficient of ${ }^{137} \mathrm{Cs}$ (left picture) and ${ }^{90} \mathrm{Sr}$ (right picture) for willow growing on different plots in Savichy

The results of specific activity measurements carried out at Masany field (Table 4) allows to evaluate the accumulation coefficient both for willow stem and leaves. In all plots of Masany field, the ${ }^{137} \mathrm{Cs}$ accumulation coefficient for leaves compared to stem is about sixfold higher. As to ${ }^{90} \mathrm{Sr}$, the accumulation coefficient for leaves is by a factor of 1.5-3.5 higher compared to that for stem. Like in Savichy, we did not reveal any significant difference of accumulation coefficient between different clones of willow.

Table 4. Content of radionuclides in soils and willow of Masany test fields

\begin{tabular}{|c|c|c|c|c|c|c|}
\hline \multirow{2}{*}{ Soil type } & \multicolumn{2}{|c|}{ T37 Cs specific activity, Bq/kg } & \multicolumn{3}{c|}{90 Sr specific activity, Bq/kg } \\
\cline { 2 - 6 } & Soil & Leaves & Stem & Soil & Leaves & Stem \\
\hline Peaty (field \#4) & $30920 \pm 3950$ & $3566 \pm 808$ & $598.8 \pm 215.2$. & $28780 \pm 12120$ & $5856 \pm 1400$ & $1998 \pm 784$ \\
\hline
\end{tabular}

\subsection{Rape}

The results of measurements of materials sampled from the rape test plantation are presented in Table 5 . The same pattern of correlation between the content of exchangeable forms of radionuclides in soil and the soil cation exchange capacity is revealed (for ${ }^{90} \mathrm{Sr}$, see Figure 3). From Figure 4 one can see that the accumulation coefficient of ${ }^{90} \mathrm{Sr}$ is about two orders of magnitude higher than that of ${ }^{137} \mathrm{Cs}$. In different parts of Brassica juncea, ${ }^{137} \mathrm{Cs}$ accumulation coefficient conforms to the following scale: stems/leaves/flowers $=1 / 1.3 / 2.5$. As to ${ }^{90} \mathrm{Sr}$ accumulation, this order is $1 / 8.5 / 3$.

Table 5. Content of radionuclides in soils and plants of the rape test fields

\begin{tabular}{|c|c|c|c|c|c|c|}
\hline \multirow{2}{*}{$\begin{array}{c}\text { Test } \\
\text { plot \# }\end{array}$} & \multicolumn{3}{|c|}{ 137/Cs specific activity, Bq/kg } & \multicolumn{3}{c|}{ Y0Sr specific activity, Bq/kg } \\
\cline { 2 - 7 } & Soil (total) & $\begin{array}{c}\text { Soil } \\
\text { (exchangeable) }\end{array}$ & Rape plant & Soil (total) & $\begin{array}{c}\text { Soil } \\
\text { (exchangeable) }\end{array}$ & Rape plant \\
\hline 1 & 1530 & 186 & 464.0 & 164 & 127 & 5278 \\
\hline 3 & 1930 & 217 & 542.2 & 152 & 120 & 5296 \\
\hline 5 & 1515 & 182 & 374.0 & 151 & 114 & 5756 \\
\hline 7 & 1200 & 126 & 285.1 & 164 & 130 & 5692 \\
\hline 9 & 1425 & 160 & 378.0 & 198 & 145 & 4504 \\
\hline
\end{tabular}




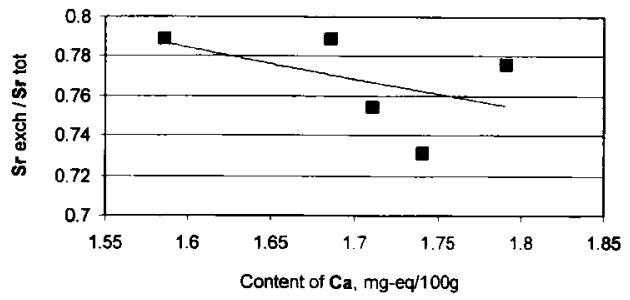

Figure 3: Relation between concentration of ${ }^{90} \mathrm{Sr}$ exchangeable forms and Ca content in rape test plots
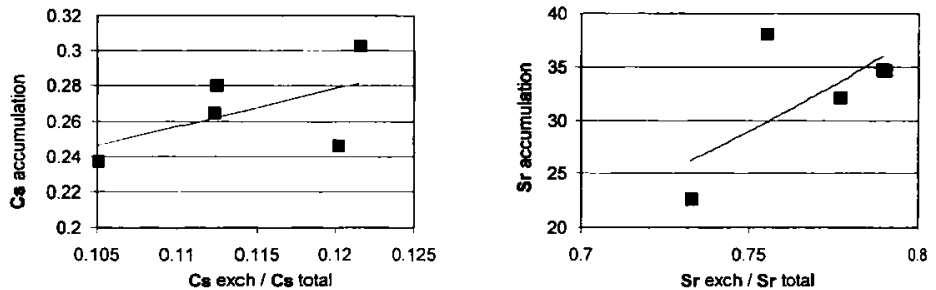

Figure 4: Accumulation coefficient of ${ }^{137} \mathrm{Cs}$ (left picture) and ${ }^{90} \mathrm{Sr}$ (right picture) for rape plant

\section{CONCLUSION}

The investigated correlation between the soil properties and the rate of extraction of radionuclides by the identified crops provides more data for sound decision on applicability of phytoremediation to radioactively contaminated area. For example, in view of relatively high ${ }^{137} \mathrm{Cs}$ transfer factor for willow wood, ranging from $0.210^{-3}$ through $1.510^{-3} \mathrm{~m}^{2} / \mathrm{kg}$, willow chips may not be applicable as a fuel if wood is extracted from the area of contamination of higher than $740 \mathrm{~Bq} / \mathrm{m}^{2}$. Otherwise, it will lead to excess of exemption limit established for wood fuel and to additional threat to population health.

\section{Acknowledgment}

The study was supported by RECOVER Project of the European Commission (DG-XII) and Initiatives for Proliferation Prevention Program of the US Department of Energy. The authors acknowledge a valuable assistance by Dr. Amold A. Gvozdev, Institute of Radio-Ecological Problems, Belarus.

\section{References}

[1] Vandenhove H., Gommers A., Thiry Y., Goor F., Jossart J.M., Holm E., Gävfert T., Roed J., Grebenkov A., Timofeyev S., and Firsakova S., "Evaluation of short rotation coppice as remediation option for contaminated farmland", The NATO Advances Research Workshop on Contaminated Forests: Recent development in Risk Identification and Future Perspectives, Kiev, Ukraine, June 1998, NATO Sciences Series, Environmental Security, VOL. 58, I. Linkov and R. Schell Eds (Kluwer Academic Publishers, USA, Massachusetts, 1999) pp. 377-384.

[2] Vandenhove H., Gommers A., Thiry Y., Goor F., Jossart J.M., Holm E., Gävfert T., Roed J. 1999. RECOVER - Relevancy of short rotation coppice vegetation for the remediation of contaminated areas, Final Report, EC-DG XIl-project F14-CT0095-002 Ic, SCKoCEN, BLG 826. 